\title{
How is REDD+ unfolding in southern Africa's dry forests? A snapshot from Mozambique
}

\author{
Sheila Wertz-Kanounnikoff ${ }^{1}$, Almeida Sitoe² and Alda Salomão ${ }^{3}$
}

\section{Key points}

- Mozambique has high forest cover, a high deforestation rate and severe forest degradation. It is also one of the poorest and most vulnerable countries in the world. Therefore, Mozambique requires a pro-poor REDD+ model that progressively widens its scope to include agriculture and adaptation.

- Mozambican experts have drafted a national REDD+ strategy, which is currently undergoing government consultation, with public dissemination to follow later in 2011. The main REDD+ initiatives in Mozambique include a Norwegian-funded South-South cooperation programme with an Brazilian institution (FAS) designed to support REDD+ strategy development, and a Japanese-funded readiness initiative on monitoring, reporting and verification and reference levels.

- Mozambique has a tradition of stakeholder consultation and relatively inclusive processes. However, to improve the content and acceptance of the REDD+ strategy and subsequent related legislation, greater capacity-building efforts and consultations are needed, especially at subnational levels, amongst communities and in the private sector.

- Important lessons for REDD+ benefit sharing can be drawn from Mozambique's innovative-yet still underimplemented - 20\% timber royalty distribution mechanism, as well as the two ongoing carbon forestry payments for environmental services schemes.

- Securing financing for REDD+ will be a challenge, and funding REDD+ implementation phases will require pooling resources from different sources. Implementation of a solid, well-developed REDD+ strategy can serve as a powerful framework to attract and coordinate such long-term financing for REDD+.

\section{Context}

Mozambique is one of the few countries in southern Africa that still has a considerable area of natural forests, mainly Miombo woodlands (Figure 1). The total forest cover is estimated at around 40 million ha, 51\% of the country (Marzoli 2007).
Miombo forests have lower wood carbon storage per hectare than humid forests, but because they cover such extensive areas, their aggregate contribution is considered large (Dewees et al. 2010). The average carbon stock in topsoil to a depth of $0.3 \mathrm{~m}$ (100 tC/ha) is estimated to be higher than the carbon stock in tree stems (19 tC/ha) (Williams et al. 2008). 


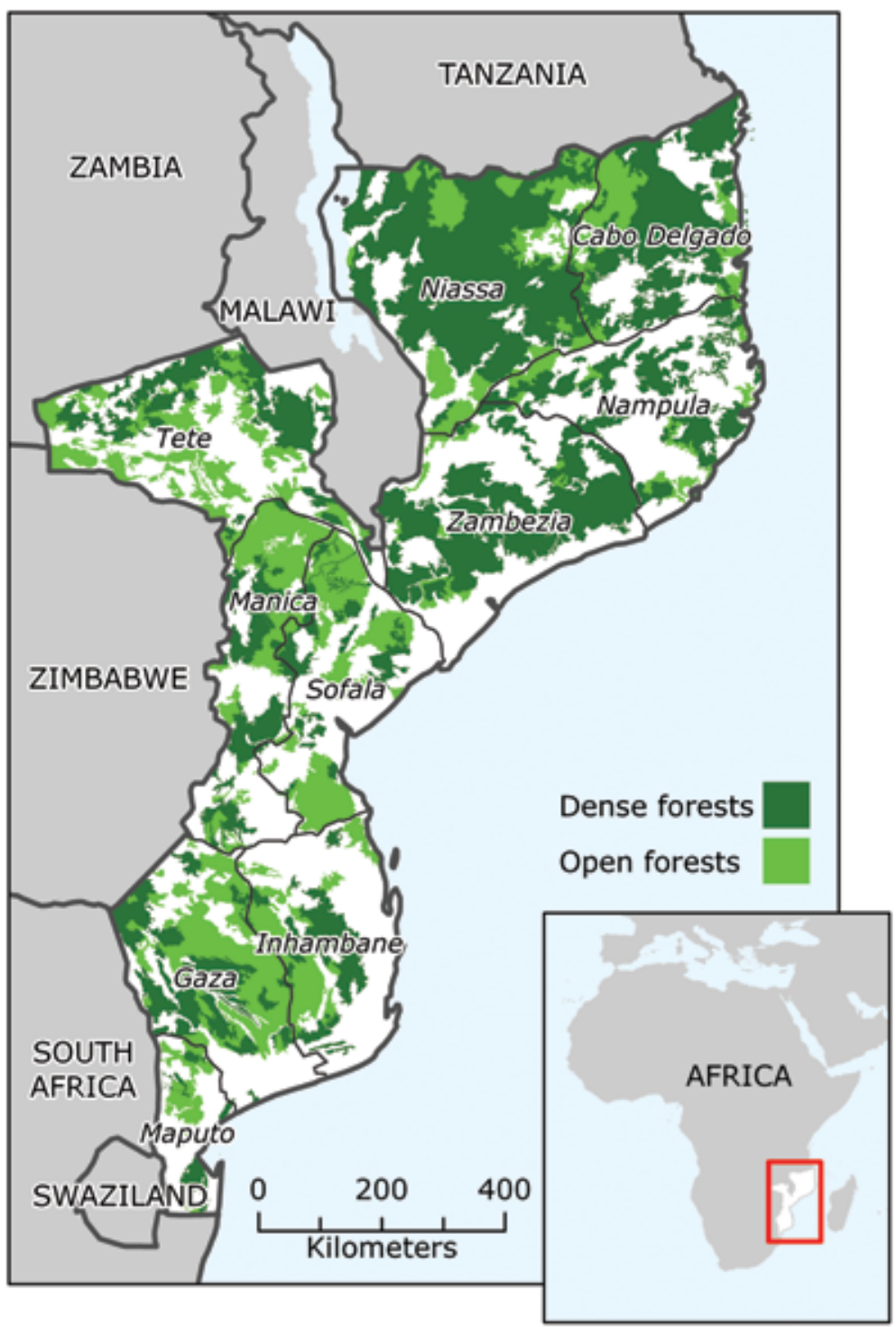

Figure 1. Forest cover of Mozambique

Source: Marzoli (2007)

Mozambique is one of the poorest countries in the world with almost $55 \%$ of the population of around 23 million living in poverty (MPD-DNAP 2010). In 2009, $62 \%$ of people lived in rural areas (World Bank 2011), and about $80 \%$ (including urban residents) rely on forest products for their livelihoods (Nhantumbo and Izidine 2009).

Mozambique is also one of the most vulnerable countries of the world. Subject to extreme weather events in response to global warming, it ranks third among the African countries most exposed to risks from multiple weather-related hazards including droughts, flooding and cyclones (UNISDR 2009, World Bank 2010).

Deforestation and forest degradation are widespread throughout the country. From 1990 to 2005, the deforestation rate was $0.58 \%$, or 219000 ha per year (Marzoli 2007). Most of the deforestation takes place in Miombo woodlands (Mozambique R-PIN 2008), generally in the most accessible areas, close to towns and roads or railways. Parker et al. (2009) classify Mozambique as a country with high forest cover (>50\%) and a high deforestation rate (>0.22\% annually). 
Table 1. Drivers of deforestation and forest degradation in Mozambique

\begin{tabular}{ll}
\hline Direct causes & Underlying causes \\
- Shifting cultivation & - Economic profitability of export markets (cotton, tobacco, timber) \\
- Permanent agriculture & - Poverty as a driving force of unsustainable practices given limited alternatives \\
- Bushfires & - Over-reliance on fuelwood, including charcoal burning \\
- Fuelwood harvesting and & - Population growth and the need for more land conversion \\
charcoal burning & - Little incentive for rural communities to maintain forest cover \\
- Illegal logging & - Inadequate harmonisation amongst policies \\
- Large-scale mining & - Inadequate implementation of policies \\
& - Poor land use planning and unplanned settlements \\
& - Limited capacity to enforce laws \\
\hline
\end{tabular}

Sources: Mozambique (R-PIN 2008) and Cuambe (2010)

Fuelwood consumption, shifting cultivation and permanent agriculture are the major drivers of deforestation in Mozambique (Table 1). Some forest clearing is also associated with mining activities, and in some provinces (e.g. Tete), mining is expected to become a major future driver of forest emissions (Cuambe 2010). Fuelwood consumption for energy (firewood and charcoal) is estimated at 9.3 and 5.5 million tonnes per year in rural and urban areas, respectively (Sitoe et al. 2007). These estimates are equivalent to an average per-capita consumption of 1-1.2 $\mathrm{m}^{3}$ per year. Although rural consumption is higher in absolute terms, deforestation is driven primarily by urban consumption, which creates areas of high demand in the most accessible forest areas around the major towns (e.g. Maputo, Beira, Nampula). Deforestation for agricultural purposes is mainly linked with tobacco, cotton and, more recently, sesame cultivation. Smallholders dominate the country's agriculture sector, particularly since the introduction of structural adjustment loans to Mozambique, which led to the collapse of agro-processing (Cramer 1999).

Degradation is believed to be an even larger problem for Mozambique's forests. Illegal logging and fire are the main drivers of forest degradation (Mackenzie 2006, Nhantumbo and Izidine 2009). A recent study estimates the cost of degradation at about US\$35 million or $0.4 \%$ of GDP (MICOA 2009 data cited in FAS 2009). At the same time, the forestry sector provides about 200000 formal jobs with an even larger number in the informal sector (Nhantumbo and Izidine 2009).

\section{REDD+ process}

In 2008, Mozambique prepared and submitted to the Forest Carbon Partnership Facility (FCPF) a Readiness Plan Idea Note (R-PIN). A National REDD+ Working Group was established in 2009. The working group's initial work plan was revised in March 2010 to accommodate 1) the emerging priority of developing a national REDD+ strategy to inform the implementation of pilot projects whilst 2) allowing the preparation of the Readiness Preparation Proposal (R-PP). The two processes were subsequently merged.

Since August 2010, the first draft REDD+ strategy document, authored by Mozambican experts, has been available for government consultation, to be followed by public consultations in 2011. The country is also considering submitting an R-PP to the FCPF.

In August 2010, Japanese cooperation started to provide financial and technical assistance for REDD+ readiness to the Department of Natural Resource Inventory at the National Directorate of Lands and Forestry of the Ministry of Agriculture (MINAG). Additionally, a technical cooperation project focusing on REDD+ MRV (monitoring, reporting and verification) and reference levels, including the provision of satellite images and GIS facilities, will run from December 2011 to 2014.

In addition, REDD+ projects are emerging on the ground. Mozambique already has two ongoing carbon forestry payments for environmental services 
(PES) projects with REDD+ components, implemented by Envirotrade, in Sofala and Cabo Delgado provinces. At least two more REDD+ demonstration activities are being prepared including one by the Mozambique Carbon Initiative $(\mathrm{MCl})$ in one of the pilot areas indicated by the draft national REDD+ strategy, and one by the civil society organization Flora and Fauna International (FFI) in Niassa Province. The possibility to mobilise REDD+ as a potential additional financing stream is also being explored at a very preliminary stage for the Gilé National Reserve in Zambezia Province.

\section{Scope and scale}

Given the country's high dependence on forests for rural livelihoods, and associated calls for a propoor approach to REDD+ in Mozambique (e.g. FAS 2009, Nhantumbo and Izidine 2009), the draft REDD+ strategy proposes a system of payments for environmental services (PES) targeting mainly local communities involved in shifting cultivation.

The draft national REDD+ strategy emphasises that the main underlying causes of deforestation and degradation in Mozambique originate from outside the forestry sector, requiring an intersectoral approach to realise REDD+. Examples of proposed actions include energy policies to increase urban access to alternative energy sources, as well as increased production of sustainable wood-based energy, and agricultural intensification, including conservation agricultural and agroforestry systems. To date, such measures have been weakly enforced; yet according to the draft national REDD+ strategy, their additionality as REDD+ action will become apparent when they are placed at the top of the policy agenda and properly implemented.

\section{Coordination and commitment}

Two government institutions are leading the REDD+ process in Mozambique: the National Directorate of
Land and Forestry under the Ministry of Agriculture (MINAG), which is responsible for implementing policies related to forest resources, and the Ministry for the Coordination of Environmental Affairs (MICOA), which is the key agency for environmental management and coordination. Although MICOA is coordinating the REDD+ strategy, and has been proposed as the home of the REDD+ Technical Group, MINAG will most likely implement most of the proposed actions. As MICOA is a trans-sectoral ministry, giving it responsibility for coordination is expected to facilitate interventions in other sectors and by ministries such as the Ministry of Energy, the Ministry of Public Works and Housing and the Ministry of Mineral Resources.

Coordination has been identified as a key challenge in implementing REDD+ in Mozambique (Mozambique R-PIN 2008, Nhantumbo and Izidine 2009). In the late 1990s and early 2000s, improvements were made to policies and legislation that enabled community participation in, and required private sector involvement for, sustainable forest management; however, little has evolved in terms of actual implementation. This limitation is evident in other sectors also, where good policies were adopted but little done to ensure their actual implementation. Coordination challenges occur at various levels, including:

- between government institutions, as mentioned;

- across administrative levels, e.g. the Mozambican R-PIN states that enforcement powers can be delegated to community-level structures, but the delegation mechanism or conditions require further clarification; and

- across forest policies, e.g. the concession policies that govern annual logging permits and longterm concessions do not offer much control over harvesting practices and the weak management of concessions results in overharvesting and low government revenues. 


\section{Participation}

Mozambique has a strong tradition of stakeholder consultation (Nhantumbo and Izidine 2009). In relation to REDD+, MICOA has been leading the stakeholder engagement and various consultative meetings have taken place (Johns et al. 2009). Although there have been some reports of difficulties in accessing information on the REDD+ process (Global Forest Coalition 2009), others have described the draft REDD+ strategy development in Mozambique as being based on a 'reasonably consultative process', especially compared with other countries ( $\varnothing$. Botillen personal communication, 30 September 2010).

A South-South cooperation programme between MICOA and the Brazilian Sustainable Amazon Foundation (FAS) has been the first main REDD+ initiative in Mozambique. Established in 2009, with technical and financial support from the Norwegian Embassy in Maputo, this initiative is designed to share experiences on REDD+ and was fundamental in realising the draft REDD+ strategy document in 2010. Members of the National REDD+ Working Group come from various national and international organisations (incl. MICOA, MINAG, FAS, Centro Terra Viva,

Universidade Eduardo Mondlane, International Institute for Environment and Development and Indufor).

Initial consultations to inform the draft REDD+ strategy were conducted in 2010 in several provinces of the north (Niassa, Nampula), centre (Zambézia, Tete) and south (Gaza) of the country (see Figure 1). Regional consultations were held in the south (Maputo), centre (Sofala) and north (Nampula). Participants in these consultations included representatives from national, provincial and district government authorities, local civil society organisations, some private companies and academia. In addition, community consultations were conducted in Tete, as were discussions with the private sector and local communities through field visits conducted by a multidisciplinary team of researchers working in Gaza, Maputo, Tete, Sofala, Niassa and Zambézia. Following government consultations on the draft REDD+ strategy (since August 2010 until at least March 2011), an extensive campaign of awareness raising and information dissemination (with greater emphasis on subnational levels and the private sector) is envisaged for 2011 (See Figure 1).

\section{Benefit sharing and distribution}

Under the Mozambican Constitution of 2004, the state owns all land; there is no private land ownership. However, use and benefits rights can be acquired based on occupancy/use or custom or by administrative grant of title. Individuals and communities have rights to the land they have traditionally occupied, and the government may authorise individuals and companies to use the land, through the DUAT (Direito de Uso e Aproveitamento de Terra) mechanism. Nearly all of Mozambique is comprised of community lands but communities are not always aware of, or have the capacity to exercise, their legal land rights (Mozambique R-PIN 2008).

As an important share of forestland is in community areas, any REDD+ activity needs the participation of rural communities. The government adopted community-based natural resource management (CBNRM) as a strategy in the 1990s and the country currently has nearly 70 CBNRM initiatives (Nhantumbo and Izidine 2009). However, as noted above, communities tend to have limited capacity to exploit benefits from their rights.

Since 2005, Mozambique has a policy under which $20 \%$ of timber royalties are to be distributed amongst local communities. However, this policy is still slow to implement with currently only 631 (57\%) of 1100+ communities having received benefits (MINAG-DNTF 2009). Reasons include difficulties in disbursement requirements and in reinvestment for communities because of their inexperience in planning and running money-based projects. For the REDD+ benefitsharing mechanism, it will be crucial to build on the lessons from this timber royalty redistribution mechanism. One proposal for simplified disbursement is to channel funds through shops, as used earlier to transfer remittances and to sell cash crops (Nhantumbo and Izidine 2009). 
The aforementioned two community-based, carbon forestry PES schemes ongoing in Mozambique can provide further lessons for benefit sharing and REDD+ policy design in general. These include the Sofala Community Carbon Project (the follow up project of the Nhambita pilot project 2002-2008) and the Quirimbas Community Carbon Project since 2008.

\section{Challenges ahead}

The Mozambican REDD+ process is remarkable in approach, ownerships and consultations. Its approach reverses the sequence of the R-PP process by writing a draft REDD+ strategy before requesting FCPF support for R-PP development. Thus far the locus of ownership is with the Mozambicans, who drafted the strategy, rather than with external consultants. And the consultations in Mozambique were more inclusive than in other countries. It thus differs from processes observed in many other REDD+ countries.

Given Mozambique's national circumstances (soil carbon as an important carbon pool, food security issues, climate change adaptation needs), a REDD+ model that progressively widens its scope to include agriculture and adaptation considerations seems justified. Valuable contributions in this respect are currently being explored, for example within the aforementioned South-South initiative.

At the same time, several challenges remain. One is the targeting and prioritisation of the proposed REDD+ policies and measures. Prioritising can ensure that the proposed REDD+ measures are effective, meaning they address the actual drivers of deforestation and degradation. Prioritising can also help identify cheaper and quicker policy interventions over more costly, longer-term transformational reforms. For example, effective measures would prioritise increasing the number of environmental control agents before reforming land tenure.

A second challenge refers to the benefit-sharing mechanism and attribution of carbon benefits.
Starting points for deriving lessons learned for the national REDD+ architecture are the innovative yet under-implemented $20 \%$ timber royalty distribution mechanism and the ongoing PES-based carbon forestry schemes.

A third challenge applies to governance aspects, notably coordination, compliance, capacity and consultation. Coordination challenges include clarification of the different roles and responsibilities between actors, and mitigating trade-offs between environmental and development objectives. Given Mozambique's history of 'paper laws and policies' (i.e. laws and policies that exist on paper but not in practice), compliance with and enforcement of laws and policies will be fundamental for REDD+ success. Closely connected to capacity is the value of consultation and participation. In principle, communities in Mozambique own significant rights, but they lack the capacity to fully exercise these rights. Furthermore, although the REDD+ consultations in 2010 (to inform the development of the draft strategy document) were targeted and contributed to enhanced awareness, greater capacity-building efforts and consultations are needed, especially at subnational levels and in the private sector. These actions, along with actual experimentation with REDD+ on the ground, can further improve the REDD+ strategy content and increase its acceptance amongst stakeholder groups, including local communities and REDD+ investors (private sector, international donors).

A fourth challenge lies in securing finance for REDD+. Currently, REDD+ in Mozambique is financed primarily by bilateral aid from Norway and Japan. However, significant funds are needed to finance the different phases of REDD+: readiness (design of national strategies and initial capacity building), strategy implementation (policies and measures for an enabling institutional environment) and performance-based actions (e.g. direct payments for REDD+). To this end, it will be necessary to pool funds from different REDD+ financing sources (i.e. bilateral, 
multilateral, private). The development and actual implementation of a solid national REDD+ strategy that adheres to international standards (including social and environmental safeguards) can serve as a powerful framework to attract and coordinate additional and long-term REDD+ finance.

\section{References}

Angelsen, A., with Brockhaus, M., Kanninen, M., Sills, E., Sunderlin, W.D. and Wertz-Kanounnikoff, S. (eds) 2009 Realising REDD+: national strategy and policy options. CIFOR, Bogor, Indonesia.

Cramer, C. 1999 Can Africa industrialize by processing primary commodities? The case of Mozambican cashew nuts. World Development 27(7): 1247-1266.

Cuambe, C. 2010 Uso da terra, oportunidades e desafios para a implementação do mecanismo de REDD+, presentation at the Mozambique REDD+ Regional Seminar in Beira, June.

Dewees, P.A., Campbell, B.M., Katerere, Y., Sitoe, A., Cunningham, A.B., Angelsen, A. and Wunder, S. 2010 Managing the Miombo woodlands of southern Africa: policies, incentives and options for the rural poor. Journal of Natural Resources Policy Research 2(1): 57-73.

Envirotrade 2010 What is the Envirotrade model? http://www.envirotrade.co.uk/html/about.php [3 March 2010].

Amazonas Sustainable Foundation (FAS) 2009 Progress report of the side-event South-South Cooperation on REDD+ during COP-15 at Copenhagen. Unpublished document of the project South-South REDD+: A Brazil-Mozambique Initiative.

Global Forest Coalition 2009 REDD realities: how strategies to reduce emissions from deforestation and forest degradation could impact on biodiversity and Indigenous Peoples in development countries. Asuncion. http://www.globalforestcoalition.org/ wp-content/uploads/2010/10/REDD-Realities.pdf [20 February 2011].
Johns, R., Johnson, E. and Greenglass, N. 2009 An overview of readiness for REDD: a compilation of readiness activities prepared on behalf of the Forum on Readiness for REDD, Version 2, December 2009. Woods Hole Research Center, Falmouth, MA, USA.

Mackenzie, C. 2006 Forest governance in Zambezia, Mozambique: Chinese takeaway! Final report for FONGZA Forum das Organização NãoGovernamental da Zambezia, Maputo. http://www. illegal-logging.info/uploads/Mozambique_China.pdf [20 February 2011].

Marzoli, A. 2007 Inventário florestal nacional. Avaliação Integrada das Florestas de Moçambique (AIFM). National Directorate of Land and Forest (DNTF), Ministry of Agriculture, Maputo, Mozambique.

MINAG-DNTF 2009 Relatório Anual 2009. National Directorate for Lands and Forestry, Ministry of Agriculture, Maputo, Mozambique.

MPD-DNEAP 2010 Poverty and wellbeing in Mozambique: third national poverty assessment. National Directorate of Studies and Policy Analysis, Ministry of Planning and Development, Maputo, Mozambique.

Mozambique R-PIN 2008 Forest Carbon Partnership Facility. Draft submitted 8 March 2008; final submitted 15 December 2008. http://www. forestcarbonpartnership.org/fcp/Node/174 [3 March 2010].

Nhantumbo, I. and Izidine, S. 2009 Preparing for REDD in dryland forests: investigating the options and potential synergy for REDD payments in the miombo eco-region: Mozambique country study. International Institute for Environment and Development (IIED), London.

Parker, C., Mitchel, A., Trivedi, M. and Mardas, N. 2009 The little REDD+ book. Global Canopy Programme, Oxford, UK. 132p.

Sitoe, A., Mirira, R. and Tchaúque, F. 2007 Avaliação dos níveis de consumo da energia de biomassa nas províncias de Tete, Nampula, Zambézia, Sofala, Gaza e Maputo. Relatório final. Ministry of Energy, Maputo, Mozambique. 37p. 
UNISDR 2009 Global Assessment Report on Disaster Risk Reduction, United Nations International Strategy for Disaster Reduction, Geneva, Switzerland.

UNFCCC 2010 Outcome of the work of the Ad Hoc Working Group on long-term Cooperative Action under the Convention, Draft decision -/CP.16 (advance unedited version) http://unfccc.int/files/ meetings/cop_16/application/pdf/cop16_Ica.pdf [14 February 2011].

Williams, M., Ryan, C.M., Rees, R.M., Sambane, E., Fernando, J. and Grace, J. 2008 Carbon sequestration and biodiversity of re-growing Miombo woodlands in Mozambique. Forest Ecology and Management 254: 145-155.
World Bank 2011 Data by country: Mozambique. http://data.worldbank.org/country/mozambique [7 March 2011].

World Bank 2010 Economics of Adaptation to Climate Change - Mozambique, World Bank, Washington, DC.

\section{Acknowledgements}

We thank Maria Brockhaus, Øystein Botillen, Isilda Nhantumbo and Andrew Wardell for valuable comments on an earlier version of this brief, and Edith Johnson and the editor Imogen Badgery-Parker for their efficient support in the publication process.

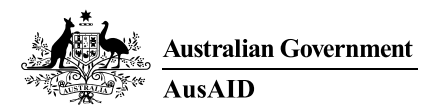

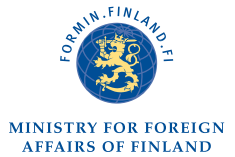

AFFAIRS OF FINLAND

\author{
the David \\ Lucile Packard
}
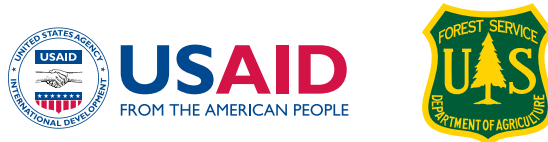